\title{
EFFECTIVENESS OF BOTANICAL INSECTICIDE FORMULATIONS AGAINST COCOA POD BORER Conopomorpha cramerella (Snell.)
}

\author{
La Ode Santiaji Bande, Gusnawaty HS, Mariadi, \& Nuriadi \\ Department of Plant Protection, Faculty of Agriculture, Halu Oleo University, Indonesia \\ Jl. HEA Mokodompit Kampus Hijau Bumi Tridharma Anduonohu Kendari 93232 \\ E-mail: 1s.bande@yahoo.co.id
}

\begin{abstract}
Effectiveness of botanical insecticide formulations against cocoa pod borer Conopomorpha cramerella (Snell.). Cocoa pod borer (CPB), Conopomorpha cramerella (Lepidoptera: Gracillariidae), is a major pest on cocoa plants. The research aimed atfinding out botanical insecticide formulations that are effective against CPB. Plant materials used for preparing the formulations were cashew nut shell (Anacardium occidentale), whiteflower albizia (Albizia saponari), siam weed (Chromolaena odorata), and candle bush (Senna alata) extract. This research was conducted in the field using a randomized complete block design with the following treatments: formulation of cashew nut shell extract, cashew nut shell extract + whiteflower albizia bark extract, cashew nut shell extract + siam weed leaf extract, cashew nut shell extract + candle bush leaf extract, cashew nut shell extract + whiteflower albizia bark extract + siam weed leaf extract + candle bush leaf extract, and a synthetic insecticide formulation containing a mixture of lambda-cyhalotrin $106 \mathrm{~g} / \mathrm{L}$ and thiametoxam $141 \mathrm{~g} / \mathrm{L}$ as well as control (without botanical and synthetic insecticide treatment). The concentration of botanical pesticides applied from cashew nut shell extract used was $2.5 \mathrm{~mL} / \mathrm{L}$, while from other ingredients $250 \mathrm{~mL} / \mathrm{L}$. Variables observed were intensity of CPB infestation, degree of damage to the cocoa seed, and the efficacy of botanical insecticide treatments. The results showed that the test botanical insecticide formulations reduced the intensity of $\mathrm{CPB}$ infestation by $48.9-55.3 \%$ and the degree of seed damage by $52.3-58.2 \%$ compared with control. The efficacy of the test botanical insecticide formulations in controlling CPB was relatively the same when compared to each other, with a range of efficacy of $64.2-71.0 \%$, but was lower than that of the synthetic insecticide formulation (92.8\% efficacy). The implication of this research is that botanical insecticide formulations have the prospect of being continuously developed and have the potential to reduce the used of synthetic insecticides.
\end{abstract}

Key words: botanical insecticide, cashew nut shell, cocoa pod borer, field efficacy, formulation

\section{INTRODUCTION}

Cocoa plantations in Indonesia are mostly cultivated in the form of smallholder plantations and generally have low production and high yield loss due to pest and disease attacks (Siswanto \& Karmawati, 2012). The main pests in cocoa are cocoa pod borer (Conopomorpha cramerella) which has spread to all cocoa-producing provinces in Indonesia with losses reaching billions of rupiah (Prastowo et al., 2010). Loss of yield due to cocoa pod borer attacks in Southeast Sulawesi Province can reach $82 \%$ (Disbunhorti Sultra, 2010).

Control by cocoa farmers on cocoa pod borer pests in the field still makes chemical insecticides the first choice as it is very practical, the results are fast, and easily seen by farmers (Siswanto \& Karmawati, 2012). The use of chemical insecticides has had negative impacts such as pest resistance (Baehaki et al., 2016), resurgence of pests (Ratna et al., 2009), pesticide residues in agricultural products and health problems of working farmers (Amilia et al., 2016). The case of finding pesticide residues in cocoa beans exported to Japan provides early warning for the emergence of pesticide residues in Indonesian cocoa beans (Wiryadiputra, 2013), and becomes a threat to the export embargo on Indonesian cocoa beans, so it is necessary to find an alternative response.

Production of cocoa beans that are free of pests and insecticide residues is a priority that must be realized by farmers to meet consumer needs. Consumers of agricultural products such as cocoa on the global market wish for agricultural production that is environmentally friendly and has clear ecolabelling. Cocoa bean products that are free of insecticide residues and come from environmentally friendly agriculture in the future will be an advantage of Indonesian cocoa production in free trade. The choice that can be made to suppress the presence of chemical pesticide residues and to secure the loss of cocoa production from pest disorders is to 
develop botanical insecticide technology by utilizing plants that are around farmers.

The opportunity to develop plant-based insecticides is very strategic and sources of botanical pesticide material have been widely studied (Wiratno et al., 2013). Local plants that have the potential to be developed as sources of botanical insecticides include cashew nut shells (Anacardium occidentale), whiteflower albizia tree (Albizia saponaria), siam weed (Chromolaena odorata), and candle bush (Senna alata) (Bande et $a l ., 2018$ ), lemongrass scented (Rohimatun \& Laba, 2013), fish-poison beans and sugar-apple (Sifa et al., 2013). Research shows that cashew nutshell extract is toxic to the larvae of Crocidolomia pavonnana (Dono \& Susanerwinur, 2013) and can be used as a molluscicide (Harlita \& Muzayyinah, 2004), while siam weed leaf extract effectively controls the armyworm Spodoptera litura (Thamrin et al., 2013). Whiteflower albizia is traditionally used as a substitute for soap and has the potential as an insecticide (Pongoh et al., 2007), whereas candle bush contains saponins so that it can be used as a botanical pesticide (Hiola \& Bahri, 2010). Extract of fish-poison beans (Tephrosia vogelii) and sugar-apple (Annona squamosa) at a concentration of $1 \%$ has the potential to be used in pest control of white flea papaya Paracoccus marginatus (Sifa et al., 2013) and leaf extract and flower extract of Tithonia diversifolia have insecticidal properties on cabbage leaf caterpillar Plutella xylostella (Firmansyah et al., 2017).

Botanical insecticides have some advantages, which are the raw material is available abundantly in nature, the active ingredients are easily decomposed so that it is relatively safe for life, they have broad spectrum, they are not generally not toxic to mammals (Wiratno et al., 2013), and they do not kill natural enemies of pests (Willis, 2010). Application of botanical pesticides from fish-poison leaf extract ( $T$. vogelii), sugar-apple seed extract ( $A$. squamosa), and the essential oil of Cinnamomum multiflorum leaves shows that botanical pesticides are safe against predatory larvae of Curinus coeruleus (Sifa et al., 2013).

The effectiveness of botanical pesticides in controlling pests can be influenced by the type of mixture of ingredients and their formulations (Kardinan \& Suriati, 2012; Wiratno et al., 2013). The formulation of calabash botanical insecticide s (Crescentia cujete) EC and WP at the lowest dose $(0.50 \mathrm{~L}$ formulation/ha) effectively reduces the intensity of the pest attack of Empoasca flavescents in tea plants by 70\% (Sucherman, 2013). Cocoa pod borer pest control with $25 \%$ candlenut formulation $+5 \%$ siam weed at a concentration of 10 $\mathrm{mL} / \mathrm{L}$ can reduce cocoa pod borer attacks by about $36 \%$ compared with no control measures (Soesanthy \& Samsudin, 2014). Botanical insecticide formulations from various plants continue to be developed so that their effectiveness in controlling cocoa pod borer pests is important to know. This study aimed to obtain a plantbased insecticide based on cashew nut shells, whiteflower albizia, siam weed leaves, and candle bush that are effective against cocoa pod borer.

\section{MATERIALS AND METHODS}

Research Site. This research was carried out in a cocoa farm owned by the Cocoa Research Sub-Station, Plantation and Horticulture Agency, Southeast Sulawesi Province, Lebo Jaya Village, Konda District, South Konawe Regency, Southeast Sulawesi Province. The research location was the endemic area of cocoa pod borer pests. The study was conducted from May to October 2016.

\section{Preparation of Plant Materials Source of Extract.}

Plant materials used in this study were cashew nut shells, whiteflower albizia bark, siam weed leaf, and candle bush. Siam weed and candle bush were obtained around the Halu Oleo University Faculty of Agriculture Experimental Field. Cashew nut shells were obtained from Lombe District, South Buton Regency, while Whiteflower albizia bark was taken in Wakontu Village, Wadaga District, West Muna Regency.

Making Botanical Insecticides. The production of botanical insecticides from siam weed leaves, candle bush and whiteflower albizia bark followed the steps stated by Bande et al. (2018). Prepared botanical insecticides were cleaned with water and dried in the sun for 3 days. Procedure for extracting botanical insecticides applied maceration method. Siam weed leaves, and candle bush and whiteflower albizia were cut into small pieces then blended until smooth. The maceration process was carried out by mixing $250 \mathrm{~g}$ of botanical insecticide into $5000 \mathrm{~mL}$ of water with the addition of $1 \mathrm{~g}$ of detergent then stored in tightly closed containers and stored for 3 days accompanied by stirring insecticides to mix with the solvent. After soaking for 3 days, then filtering was done using gauze. The filter results were in the form of a stored suspension for later use. Cashew nut shell extract was obtained from $\mathrm{Mr}$. Ir. Mariadi, M.Sc. from the Halu Oleo University Faculty of Agriculture.

Research Design. The study was compiled based on a randomized block design consisting of seven 
treatments, namely extract formulation of (1) cashew nut shell, (2) cashew nut shell + whiteflower albizia bark, (3) cashew nut shell + siam weed leaf, (4) cashew nut shell + candle bush extract, (5) cashew nut shell + whiteflower albizia bark + siam weed leaf + candle bush , and (6) synthetic insecticides made from lamdacyhalothrin $106 \mathrm{~g} / \mathrm{L}+$ tiametoxam $141 \mathrm{~g} / \mathrm{L}$, and (7) control (without treatment of botanical and synthetic insecticides). The concentration of cashew nut shell extract used was $2.5 \mathrm{~mL} / \mathrm{L}$, while the extract of other ingredients was $250 \mathrm{~mL} / \mathrm{L}$. Each treatment was repeated three times. Each treatment unit consisted of three cocoa plants, and the treatment plot was limited by one row of plants.

Application of Insecticides in the Field. The application of botanical and chemical insecticide formulations was carried out every week according to the treatment using back sprayers for eight times and spraying was done in the morning. Each test formulation was sprayed on 5-8 cm fruit and fruit appeared later after one month of the same size. The fruit that has been sprayed was labeled on its stem.

Observation. Observations were made on all fruits sprayed on all treated trees. Harvesting was done several times according to the fruit maturity. The effectiveness of plant-based insecticides on cocoa pod borer pests was assessed based on data on the intensity of attacks, the intensity of damage to cocoa beans, and the efficacy of botanical insecticide formulations. The intensity of cocoa pod borer pest attacks was calculated at harvest with the following formula (Purwaningsih et al., 2014):

$$
\text { IS }=\frac{\sum(\mathrm{ni} \times \mathrm{vi})}{\mathrm{Z} \times \mathrm{N}} \times 100 \%
$$

IS = intensity of cocoa pod borer attacks

$\mathrm{n}_{\mathrm{i}}=$ number of damaged fruits in each attack category

$\mathrm{v}_{\mathrm{i}}=$ the value of each attack category

$\mathrm{Z}=$ highest damage category value

$\mathrm{N}=$ number of fruits observed

The scale value of each attack category used is as follows:

$0=$ healthy fruit (no sticky seeds)

$1=$ less than $21 \%$ of the seeds on the fruit stick together

$2=21-40 \%$ of the seeds on the fruit stick together

$3=41-60 \%$ of the seeds on the fruit stick together

$4=61-80 \%$ of the seeds on the fruit stick together

$5=$ more than $80 \%$ of the seeds on the fruit stick together
The seed damage intensity (SDI) was calculated by the following formula (Nuriadi \& Gusnawaty, 2013):

$$
\mathrm{SDI}=\frac{\sum \text { broken seeds }}{\sum \text { overall seeds }} \times 100 \%
$$

The efficacy of the tested botanical insecticide formulations was calculated using the following formula (Ditjen PSP, 2011):

$$
\mathrm{EI}=\frac{\mathrm{Ca}-\mathrm{Ta}}{\mathrm{Ca}} \times 100 \%
$$

$\mathrm{EI}=$ efficacy of tested insecticides (\%)

$\mathrm{Ca}=$ intensity of seed damage in the control plot after application of botanical insecticides

$\mathrm{Ta}=$ intensity of seed damage in the treatment plot after application of botanical insecticides

Data Analysis. Data from the observations were transformed into arcsin values and then analyzed by variance using SPSS 17.0 software. If $F_{\text {count }}$ was greater than $\mathrm{F}_{\text {table }}$, statistical analysis was continued with Duncan's multiple distance test at the 5\% level.

\section{RESULTS AND DISCUSSION}

Attack Intensity and Seed Damage Intensity. The results showed that the application of botanical insecticide formulations based on cashew nut shell extract, whiteflower albizia, candle bush, and siam weed leaves can reduce the intensity of cocoa pod borer pest attacks and the intensity of damage to cocoa beans. The intensity of cocoa pod borer pest attacks and the intensity of damage to seeds varies depending on the treatment (Table 1). The intensity of cocoa pod borer pest attack and the lowest intensity of seed damage was found in the treatment with cashew nut shell extract formulations + siam weed leaf extract, which was not significantly different from the treatment of other botanical insecticides but was significantly different from the control. The intensity of cocoa pod borer attacks and the intensity of damage to the lowest cocoa beans were found in the treatment of synthetic insecticides. Cocoa plants without the treatment of botanical insecticides and synthetic insecticides had the intensity of cocoa pod borer attacks and the high intensity of cocoa beans which was $83.3 \%$ and $81.4 \%$. The application of plant-based insecticides significantly reduced the intensity of cocoa pod borer pest attacks and the intensity of damage to cocoa beans. The formulation of botanical insecticides reduced the 
Table 1. Intensity of cocoa fruit borer attacks and the intensity of damage to cocoa beans in various plant-based pesticide formulations

\begin{tabular}{|c|c|c|}
\hline Treatment $^{\mathrm{a}}$ & $\begin{array}{c}\text { Intensity } \\
\text { of cocoa } \\
\text { pod } \\
\text { borer } \\
\text { attacks } \\
(\%)\end{array}$ & $\begin{array}{c}\text { Intesity of } \\
\text { damage to } \\
\text { cocoa } \\
\text { beans } \\
(\%)\end{array}$ \\
\hline Without the application of botanical insecticides and synthetic insecticides & $83.3 \mathrm{a}$ & $81.4 \mathrm{a}$ \\
\hline F.e. cashew nut shell & $31.4 \mathrm{~b}$ & $26.3 b$ \\
\hline F.e. cashew nut shell + whiteflower albizia & $34.4 \mathrm{~b}$ & $29.1 b$ \\
\hline F.e. cashew nut shell + left leaves & $28.0 \mathrm{~b}$ & $23.2 \mathrm{~b}$ \\
\hline F.e. cashew nut shell + candle bush & $29.1 b$ & $24.3 b$ \\
\hline F.e. cashew nut shell + whiteflower albizia + siam weed leaf + candle bush & $32.2 b$ & $26.1 b$ \\
\hline Synthetic insecticides made from lamda-cyhalothrin $106 \mathrm{~g} / \mathrm{L}+$ tiametoksam $141 \mathrm{~g} / \mathrm{L}$ & $8.2 \mathrm{c}$ & $6.0 \mathrm{c}$ \\
\hline
\end{tabular}

${ }^{\mathrm{a}}$ F.e. $=$ extract formulation; ${ }^{\mathrm{b}}$ The numbers in the same column followed by the same letters are not significantly different based on Duncan's multiple hose test at the $5 \%$ level.

intensity of cocoa pod borer attacks by $48.9-55.3 \%$ and the intensity of seed damage was $52.3-58.2 \%$ when compared to controls. The ability of plant-based insecticides to reduce the intensity of seed damage shows that the trial formulations of botanical insecticides had the prospect of continuing to be developed and had the potential to reduce the use of synthetic insecticides.

Botanical insecticides formulation which had the highest potential in reducing the intensity of cocoa pod borer attacks and the intensity of damage to seeds was the formulation of cashew nut shell extract + siam weed leaf extract with the intensity of attacks and the intensity of seed damage was $28.0 \%$ and $23.2 \%$. The results of this study indicate that the application of botanical insecticides formulations of cashew nut extract + siam weed leaf extract could reduce damage to cocoa beans due to cocoa pod borer pests around $58.3 \%$ when compared to controls. The ability of cashew nut shell extracts to reduce the intensity of CPB pest attacks and the intensity of damage to seeds was because cashew nut shell contain cashew nut shell liquid (CNSL) which is a natural phenol compound in the form of anacardic acid. Tamarardic acid has an activity as an insecticide because it can inhibit the work of the enzyme prostaglandin synthetase, an enzyme needed for the formation of prostaglandins which plays a role in the reproductive physiology system of insects (Harlita \& Muzayyinah, 2004). CNSL can cause Helopeltis antonii death (Atmadja \& Wahyono, 2006) and toxic to the cabbage pest Crocidolomia pavonana, decrease the larva's eating activity and reduce the number of eggs placed by the female imago (Dono \& Susanerwinur, 2013). Spraying cashew nut shell extract on cocoa fruit can coat the skin of the fruit so that it prevents cocoa pod borer from laying eggs.

Efficacy of Botanical Insecticide Formulations. The efficacy level of each botanical insecticide formulation was not significantly different and only significantly different from synthetic insecticides (Table 2). The formulation of cashew nutshell extract has an efficacy of $68.3 \%$ and if the formulation is added with whiteflower albizia extract the efficacy is only $64.3 \%$. Whiteflower albizia contains saponins, triterpene, alkaloids, steroids, and flavonoids (Pongoh et al., 2007). Saponins affect the damage of insect skin cell walls and reduce the tension of the cytoplasmic surface of the insects (Mardiningsih et al., 2010).

The addition of siam weed leaf extract to the formulation of cashew nut shell extract caused its efficacy to increase to $71.0 \%$, while the addition of candle bush extract had an effectiveness of $70.0 \%$. Increasing the effectiveness of cashew nut shell extract formulations after adding siam weed leaf extract showed that the two active ingredients of these insecticides could be complementary. Siam weed extract contains pyrolizidine alkaloids which are toxic to insects (Thamrin et al., 2013).

The efficacy of botanical insecticide formulations used in this study ranged from $64.2-71.0 \%$ which were not significantly different between the treatments of formulations, while the efficacy of synthetic insecticides 
Table 2. The efficacy of the treatment of botanical pesticide formulations for cocoa pod borer pests

\begin{tabular}{lc}
\multicolumn{1}{c}{ Treatment $^{\mathrm{a}}$} & Efficacy level $^{\mathrm{b}}$ \\
& $(\%)$ \\
\hline F.e. cashew nut shell & $68.3 \mathrm{~b}$ \\
F.e. Cashew nut shell + Whiteflower albizia & $64.2 \mathrm{~b}$ \\
F.e. Cashew nut shell + left leaves & $71.0 \mathrm{~b}$ \\
F.e. Cashew nut shell + Candle bush & $70.0 \mathrm{~b}$ \\
F.e. Cashew nut shell + Whiteflower albizia + Siam weed leaf + Candle bush & $68.2 \mathrm{~b}$ \\
Synthetic insecticides made from lamda-cyhalothrin and tiamethoxam & $92.8 \mathrm{a}$ \\
\hline
\end{tabular}

${ }^{\mathrm{a}}$ F.e. $=$ extract formulation; ${ }^{\mathrm{b}}$ The numbers followed by the same letters are not significantly different based on Duncan's multiple hose test at the real level 5\%.

made from lamda-cyhalotrin and tiametoxam were $92.8 \%$ which was significantly higher than other treatments. The effective plant insecticides used in this study were only found in the formulation of cashew nut shell extract + candle bush and cashew nut shells + siam weed leaves because its effectiveness was $\geq 70 \%$. The criteria for tested insecticide were said to be effective if the level of efficacy was $\geq 70 \%$ (Kementerian Pertanian, 2015). The efficacy of botanical insecticide formulations which was a mixture of extracts of four types of plants (cashew nut shell + whiteflower albizia + siam weed leaf + candle bush) was no better than the formulations containing only cashew nut extract. This provides information that the formulations of various ingredients are not always better than one ingredient or two formulation source materials. Mixing a number of botanical pesticides can be synergistic so that they can increase their effectiveness or antagonists thereby reducing their effectiveness (Akhtar \& Isman, 2013).

The high efficacy of synthetic insecticides is lamda-cyhalotrin + tiametoksam because it is a synthetic insecticide whose active ingredients have been tested. These insecticides are widely used by cocoa farmers to control fruit-sucking pests $(H$. antonii) and cocoa pod borer $(C$. cramerella). This insecticide is a pyrethroid and neonicotinoid class insecticide which enters the body of insects through contact and stomach poisons (Ditjen PSP, 2014). The results of this study also provide information that in an effort to reduce the use of synthetic chemical pesticides, farmers can choose botanical insecticide formulations of cashew nut extract+siam weed leaf extract as alternative pesticides because these plant insecticides are effective in controlling CPB pests.
The use of botanical insecticides extracts of cashew nut shell + siam weed leaf extract at the farm level needs to be encouraged as one component in integrated pest control of cocoa pod borer pests. This insectide has advantages in terms of ease of obtaining raw materials because it is widely available in nature (Bande et al., 2014) and easily decomposed so as not to cause residue in cocoa beans. It can be found in various land use systems, but it is the easiest and mostly is found growing in vacant land that is not maintained (Suharjo \& Aeny, 2011).

\section{CONCLUSION}

The formulation of botanical insecticides significantly decreases the intensity of cocoa pod borer pest attacks and the intensity of damage to cocoa beans. The formulation of cashew nut shell extract + siam weed leaf extract has a high ability to control CPB pests with the intensity of attacks and the intensity of damage to cocoa beans by $28.0 \%$ and $23.2 \%$ respectively. The efficacy of insecticide formulations in controlling cocoa pod borer pests is relatively the same in each formulation, which is $64.2-71.0 \%$, but lower than the efficacy of synthetic insecticides made from lamda-cyhalotrin + tiametoxam amounted to $92.8 \%$.

\section{ACKNOWLEDGMENTS}

The author would like to thank the Ministry of Research, Technology and Higher Education for the funds provided through Higher Education Leading Research (PUPT) Fiscal Year 2016. 


\section{REFERENCES}

Akhtar Y \& Isman MB. 2013. Plant natural products for pest management: The magic of mixtures. In: Ishaaya I, Palli SR, \& Horowitz AR (Eds.). Advanced Technologies for Managing Insect Pests. pp. 231-24. Springer Netherlands.

Amilia E, Joy B, \& Sunardi. 2016. Residu pestisida pada tanaman hortikultura (studi kasus di Desa Cihanjuang Rahayu Kecamatan Parongpong Kabupaten Bandung Barat). Jurnal Agrikultura. 27(1): 23-29.

Atmadja WR \& Wahyono TE. 2006. Pengaruh cashew nut shell liquid (CNSL) terhadap mortalitas Helopeltis antonii Sign pada bibit jambu mete. Bul. Littro. 17(2): 66-71.

Baehaki SE, Iswanto EH, \& Munawar D. 2016. Resistensi wereng cokelat terhadap insektisida yang beredar di sentra produksi padi. Penelitian Pertanian Tanaman Pangan. 35(2): 99-108.

Bande LOS, Halim, \& Resman. 2014. Pemanfaatan sumber daya insitu untuk pengembangan budidaya kakao sehat yang ramah lingkungan. In: Saptarina D, Tangahu BV, Herumurti W, Erli KDM \& Umilia E (Eds.). Prosiding Seminar Nasional Pusat Studi Lingkungan. pp 41-47. Pusat Studi Permukiman dan Lingkungan Hidup LPPM ITS, Surabaya.

Bande LOS, Muhidin, Gusnawaty HS, Mariadi, Nuriadi, \& Basanunggu M. 2018. Effectiveness of botanical pesticides composite to decrease of Phytophthora palmivora caused black pod rot on cocoa. J. Agron. 17(3): 154-160.

Disbunhorti Sultra (Dinas Perkebunan dan Hortikultura Provinsi Sulawesi Tenggara). 2010. Statistik Perkebunan Sulawesi Tenggara. Disbunhorti Provinsi Sultra, Kendari.

Ditjen PSP (Direktorat Jenderal Prasarana dan Sarana Pertanian). 2011. Pedoman Umum Skrining Pestisida. Ditjen PSP, Kementerian Pertanian Republik Indonesia, Jakarta.

Ditjen PSP (Direktorat Jenderal Prasarana dan Sarana Pertanian). 2014. Pestisida Pertanian dan Kehutanan Terdaftar 2014. Ditjen PSP, Kementerian Pertanian Republik Indonesia, Jakarta.
Dono D \& Susanerwinur. 2013. Toksisitas dan antioviposisi ekstrak metanol kulit biji jambu mete (Anacardium occidentale L.) (Anacardiaceae) terhadap Crocidolomia pavonana F. (Lepidoptera: Pyralidae). Bionatura. 15(2): 79 82.

Firmansyah, Dadang, \& Anwar R. 2017. Aktivitas insektisida ekstrak Tithonia diversifolia (Hemsl.) A. Gray (Asteraceae) terhadap ulat daun kubis Plutella xylostella (L.) (Lepidoptera: Yponomeutidae). J. HPT. Tropika.17(2): 185193.

Harlita \& Muzayyinah. 2004. Serbuk kulit biji jambu mete (Anacardium occidentale Linn.) sebagai moluskisida untuk menghambat perkembangbiakan keong emas (Pomacea sp.). BioSMART 6(1): 29-32.

Hiola SF \& Bahri A. 2010. Uji toksisitas daun ketepeng cina (Cassia alata L.) pada keong mas (Pomacea canaliculata L). Bionature. 11(2): 115-119.

Kardinan A\& Suriati S. 2012. Efektivitas pestisida nabati terhadap serangan hama pada teh (Camellia sinensisL.). Bul. Littro. 23(2): 148-152

Kementerian Pertanian. 2015. Peraturan Menteri Pertanian Republik Indonesia Nomor 39/ Permentan/SR.330/7/2015 tentang Pendaftaran Pestisida. Kementerian Pertanian, Jakarta.

Mardiningsih TL, Sukmana C, Tarigan N, \& Suriati S. 2010. Efektivitas insektisida nabati berbahan aktif azadirachtin dan saponin terhadap mortalitas dan intensitas serangan Aphis gossypii Glover. Bul. Littro. 21(2): 171-183.

Nuriadi \& Gusnawaty HS. 2013. Kaji tindak pengendalian hama penggerak buah kakao (Conopomorpha cramerella Snellen) dengan pestisida nabati. Jurnal Agroteknos. 3(1): 1418.

Pongoh EJ, Rumampuk RJ, Bahti HH, Tarigan P, Mitova M, \& Blunt JW. 2007. Suatu pentahidroksiflavanon dari akar Albizia saponaria. Jurnal Kimia Indonesia. 2(1):1316.

Prastowo B, Karmawati E, Rubijo S, Indrawanto C, \& Munarso SJ. 2010. Budidaya dan Pasca Panen Kakao. Pusat Penelitian dan Pengembangan Perkebunan, Bogor. 
Purwaningsih A, Mudjiono G, \& Karindah S. 2014. Pengaruh pengelolaan habitat terhadap serangan penggerek buah Conopomorpha cramerella dan kepik Helopeltis antonii pada kakao. J. TIDP. 1(3): 149-156.

Ratna Y, Trisyono YA, Untung K, \& Indradewa D. 2009. Resurjensi serangga hama karena perubahan fisiologi tanaman dan serangga sasaran setelah aplikasi insektisida. JPTI. 15(2): 55-64.

Rohimatun \& Laba IW. 2013. Efektivitas insektisida minyak serai wangi dan cengkeh terhadap hama pengisap buah lada (Dasynus piperis China). Bul. Littro. 24(1): 26-34.

Sifa A, Prijono D, \& Rauf A. 2013. Keefektifan tiga jenis insektisida nabati terhadap kutu putih pepaya Paracoccus marginatus dan keamanannya terhadap larva kumbang predator Curinus coeruleus. J. HPT Tropika. 13(2): 124-132.

Siswanto \& Karmawati E. 2012. Pengendalian hama utama kakao (Canopomorpha cramerella dan Helopeltis spp.) dengan pestisida nabati dan agens hayati. Perspektif. 11(2): 103-112.

Soesanthy F \& Samsudin. 2014. Pengaruh beberapa jenis formula insektisida nabati untuk melindungi buah kakao dari serangan penggerek. J. TIDP. 1(2): 69-78

Sucherman O. 2013. Efektivitas formulasi insektisida nabati brenuk (Crescentia cujete) terhadap hama Empoasca flavescens pada tanaman teh. Jurnal Penelitian Teh dan Kina. 16(1): 25-36.
Suharjo R \& Aeny TN. 2011. Eksplorasi potensi gulma siam (Chromolaena odorata) sebagai biofungisida pengendali Phytophthora palmivora yang diisolasi dari buah kakao. J. HPT Tropika. 11(2): 201-209.

Thamrin M, Asikin S, \& Willis W. 2013. Tumbuhan kirinyu Chromolaena odorata (L) (Asteraceae: Asterales) sebagai insektisida nabati untuk mengendalikan ulat grayak Spodoptera litura. J. Litbang Pert. 32(3): 112-121.

Willis M. 2010. Formulasi Pestisida Nabati Berbahan Aktif Eugenol, Sitronela, Sinamaldehid, Curcumin dan Xanthorizol yang Efektif Menekan Canopomorpha cramerella dan Helopeltis sp. pada Kakao (40-50\%) dan Tidak Membunuh Musuh Alami. Laporan Akhir Program Insentif Riset Terapan. Badan Penelitian dan Pengembangan Pertanian. Pusat Penelitian dan Pengembangan Perkebunan. Balai Penelitian Tanaman Obat dan Aromatik, Bogor.

Wiratno, Siswanto, \& Trisawa IM. 2013. Perkembangan penelitian, formulasi, dan pemanfaatan pestisida nabati. J. Litbang Pert. 32(4): 150-155.

Wiryadiputra S. 2013. Residu pestisida pada biji kakao Indonesia dan produk variannya, serta upaya penanggulangannya. Review Penelitian Kopi dan Kakao. 1(1): 39-61. 